\title{
CONTROL OF THE SINGLE FIRM: ITS PLACE IN ANTITRUST POLICY
}

\author{
Corwin D. EDwards*
}

Curbs upon restrictive agreements among independent firms and curbs upon restrictive behavior of single enterprises were coupled at the inception of the American antitrust policy. The Sherman $\mathrm{Act}^{1}$ forbids not only contracts in restraint of trade and conspiracies to monopolize but also monopolization by single firms. In early decisions the courts made no sharp distinction between the two categories of restraint. Indeed, since the principles of the common law from which the antitrust policy drew its ideas had been intended primarily to protect opportunities to do business, there was no logical reason to distinguish frustration of such opportunities by a single enterprise from similar frustration of them by a group. So far as the early formulations of antitrust policy were affected by economic theory, a distinction between individual conduct and group conduct was equally inappropriate. Economists used the term monopoly to mean a degree of concentrated control so great as to give decisive power whether that power was possessed by a single enterprise or by a group of enterprises acting in concert. A single standard of appraisal was applied in economics as it tended to be in the law.

The divergencies between the treatment of groups and single firms that soon developed in the application of the Sherman Act were due not to differences in standards of evaluation but to differences in the feasibility of applying these standards to different patterns of restriction. Agreements are usually explicit. Their content is separate from the portions of business activity that are not subjects of agreement. Agreements are deliberately made, and their purposes are stated or can readily be inferred from their terms. Monopolization, however, is a pattern of power, purpose, and conduct that has no segregated identity. It must be perceived in the size and structure of the firm and the way the firm does business. Since some categories of agreements are clearly restrictive, they can be considered unlawful per se. No equivalent category of per se monopolization can be devised.

The significance of the difference is apparent in considering questions as to the effectiveness of the two types of restriction. If the parties to an agreement contend that it does not restrain trade because the contemplated restrictions are thwarted by

- A.B. 1920, B. Jour. 1921, University of Missouri; B. Litt. 1924, Oxford University; Ph.D. 1928, Cornell University. Professor of Economics, University of Oregon. Author, Maintaining Competimion (1949); Big Business and the Policy of Competition (1955); The Price Discrimination Law (I959).

${ }_{26} 6$ Stat. 209 ( 1890$)$, as amended, 15 U.S.C. $\$ \$ I-7\left(I_{9} 64\right)$. 
the countervailing activities of nonparticipants, the argument can be disregarded on the common-sense ground that people do not trouble to enter into and abide by undertakings that achieve nothing. No similar brush-off can be given to a single firm's contention that it cannot restrain trade because it lacks monopoly power. Even a firm that produces roo per cent of the available supply may lack monopoly power: it may be the last survivor of a dying industry or the first-comer into a field that can be and will be entered with no difficulty by numerous others.

Similarly, where there are claims that restriction is beneficial, appraisal and appropriate action are easier in the case of agreements than in the case of monopolization. Being explicit and separate, an agreement can be modified to eliminate from it what is found to be restrictive in purpose without destroying what is nonrestrictive or such of the restrictions as are merely ancillary to a proper purpose. Moreover, wherc the entire agreement is struck down, the participating firms remain intact, free to find ways of accomplishing their nonrestrictive purposes by individual action. In the case of monopolization, appropriate correctives are harder to devise. If a powerful firm's conduct has beneficial aspects, they are hard to disentangle from its restrictive activities; for what a firm does tends to be blended into a coherent whole, which, in a powerful firm, expresses its power. Dissolution of a monopoly, or even substantial reduction of its power, changes the firm and thus may alter all aspects of its conduct whether restrictive or not. The effect of the change upon the firm's desirable activities will be sometimes clearly bad and often problematical. Those who enforce the law may have only the choice of forbidding or permitting some blend of restrictions and nonrestrictive activities.

Because of these characteristics of the problem, the law about monopolization differs from the law about restrictive agreements in spite of identity in the underlying meaning of restriction. Agreements are appraised by their content, not by the impact derived from their coverage of a market. Firms with no preponderant place in total sales are forbidden to take collective action to fix prices, restrict output, or boycott outsiders. A single firm that covers the same portion of total sales may set its own prices, restrict its own output, or withhold its goods from whomever it chooses. As Europeans have correctly commented, the discrepancy in the application of the law tends to encourage the establishment of unitary large enterprises instead of cartels.

In a crude analysis, such a differentiation between single-firm and multi-firm monopoly is likely to be regarded as merely formal. According to this view, a single firm, curbed by its rivals, has incentives to engage in restrictions only where it has attained a monopoly position. Similarly, it is argued that, while groups of firms have pervasive incentives to avoid competition, they in fact cannot and will not combine by agreement unless collectively they too have a monopoly position. Though lesser restrictive agreements are theoretically forbidden, they will appear 
only by miscalculation and will disappear promptly whether they are unlawful or not.

The insufficiency of such an analysis is made evident by observation. In Europe, where laws allow considerable scope for cartelization, agreements by firms that do not collectively monopolize their kind of business activity are common and often are not ephemeral. In the United States, large enterprises that do not monopolize their fields of activity exercise significant degrees of discretion in their price policies, their policies as to levels of output, and their choice of customers. Restriction without preponderant monopoly power is apparently possible.

\section{II}

Though economic theorists have given little attention to the phenomenon of the nondominant cartel, they have developed sophisticated explanations for restrictive behavior by firms that have not attained monopoly. The theory of oligopoly recognizes that, in a market consisting of a few firms, independent decisions by each firm, expressing a desire to avoid retaliatory competitive action, may have results similar to those of a restrictive agreement. Theories of imperfect competition recognize that by differentiating products, taking advantage of such natural obstacles to full competition as exist in actual markets, and introducing further obstacles, firms can resort in significant degree to restrictive action. These theories conceive the interaction of business enterprises as a blend of competition and monopoly in a proportion that varies with the environment. Unfortunately, the theorists have developed little that is useful in identifying the degree of restriction that needs corrective public action. Indeed, by insisting that there are restrictive elements in the conduct of any corner grocery, they have blurred the previously clear distinction between firms that manifest these elements sufficiently to express decisive power and firms that do not have such power. ${ }^{2}$

If the Sherman Act had been written after the United States became aware of the importance of oligopoly, of product differentiation, and of imperfectly competitive markets, its concepts of market power probably would have been formulated more comprehensively. In the corresponding European legislation of the post-war period, single firms are subjected in several countries to some degree of surveillance and control when they are "dominant" or have "substantial influence." Such a degree of power is often attributed to firms that possess substantial but not preponderant market shares, size substantially larger than others with whom they compete or deal, and products that have attained an exceptional degree of differentiated prestige. Consequently, the requisite degree of power is often attributed to more than one firm in a given industry. In these countries, control of the conduct of single firms tends to cover oligopolists as well as monopolists.

\footnotetext{
'In this paper the term monopoly will continue to have the older meaning, and other terms will be used for firms that have smaller amounts of power.
} 
Since the Sherman Act antedates public awareness of the importance of restrictions by single firms that fall short of monopoly power, its application to such firms has been limited. Ingenious efforts have been made to use it against them. Concepts of restrictive agreement have been broadened to the extent that agreement has been inferred from similar action where there had been a prior exchange of views ${ }^{3}$ or where each actor acted because he knew that others were doing likewise. ${ }^{4}$ Extensions of the concept of conspiracy have eroded the difference between overt agreement and independent decision by each oligopolist in the light of what his rivals are likely to do. Concepts of monopolization have also been broadened, and monopoly has been attributed to firms that control a segregable part of a market ${ }^{5}$ and even to firms that control dealings with a single important customer. ${ }^{0}$ The Sherman Act is applied to more oligopolistic behavior than its authors would have thought possible.

Nevertheless, most of the restrictive activities of powerful oligopolists have remained immune from antitrust control. In significant portions of the parts of the economy that such firms dominate, prices have been unresponsive to environmental change or have displayed a ratchet-like capacity to move upward but not downward. ${ }^{7}$ Similarities and identities in the conduct of ostensible competitors have persisted not only where they were explicable as manifestations of competition but also where they were not. In significant industrial fields, rates of business activity and employment rather than prices have borne the principal impact of environmental change even when the level of prices was so high that leading firms could make profits while operating at half their capacity or less. ${ }^{8}$

Much of the ability that might have been used to compete in costs and prices has been diverted to strategies designed to avoid such competition or to take advantage of its absence. Some of these have been useful to the economy, technological innovation and product development being the most obvious. Others, however, have consisted chiefly of manipulative use of power to the detriment of the buyer.

Large firms that eschewed price competition have used product differentiation and planned obsolescence not only where response to varying tastes and evolving technology made such practices appropriate but also where functionally meaningless diversity of products would blunt the edge of competition. Expenditures by large

\footnotetext{
Esco Corp. v. United States, 340 F.2d 1000 (9th Cir. 1965).

- Interstate Circuit, Inc. v. United States, 306 U.S. 208 (1939).

'Farmer's Guide Publishing Co. v. Prairie Farmer Publishing Co., 293 U.S. 268 (1934).

- United States v. Yellow Cab Co., 332 U.S. 218 (1947).

'See J. M. Clark, Competition as a Dynamic Process 434 (Ig6r).

${ }^{8}$ See, e.g., Staff of Stbcomm. on Antitrust and Monopoly, Senate Coms. on the Judiciary, 88th Cong., ist Sess., Administered Prices: A Compendium on Public Policy 223-24 (Comm. Print i963); Staff of Subcomm. on Antitrust and Monopoly, Senate Comm. on the Judiciany, 85Th CoNG., 2D Sess., ADMinistered Prices: Automobiles ir2-15 (Comm. Print 1958).
} 
firms on promotional activity have become more elaborate and more costly, ${ }^{9}$ so much so as often to jeopardize small competitors. ${ }^{10}$ Significant parts of these expenditures have been used to enhance the authority of suppliers over their distributors ${ }^{11}$ and to finance the development and use of new ways to exploit the ignorance and gullibility of consumers. Particularly, they have been used to persuade buyers of the importance of functionally meaningless product differentiation and fancification. ${ }^{12}$ A mixture of activities-from innovations in products and processes to deliberate impairment of the durability and comparability of simple commodities, from informative advertising to misleading assertion and deceptive packaginghas been described as "nonprice competition." Firms engaged in it have argued that it is an adequate substitute for price competition. ${ }^{13}$ Where the substitution has taken place as an expression of the power of powerful firms but without collusion among them, the antitrust laws have not been adequate to prevent it.

A possible public policy would be to supplement the antitrust laws by legislation designed to cope with the restrictive activities of powerful firms by regulatory controls. Since the second World War some European countries have imposed such controls upon large firms as to prices and selection of customers. Denmark requires influential firms to obtain the government's consent before raising their prices. France requires large and small firms alike to sell to all buyers who seek in good faith to enter into normal transactions. Several countries apply more modest statutes that express similar policies. ${ }^{14}$ Even in the United States, proposals have been recurrently made to Congress that large firms be required to give the government advance notice of price increases. ${ }^{15}$

A second possible policy would be to modify the antitrust laws, by new legislation or by interpretation of the old, so that they would rest upon a distinction

These expenditures have differed in magnitude from one industry to another. In $196_{3}$, according to Advertising Age, Aug. 3x, 1964, p. 36, General Motors Corp. spent upon advertising \$I6o million, about I\% of sales; Procter \& Gamble Co., \$200 million, over 10\% of sales; Colgate-Palmolive Co., $\$ 74$ million, nearly $22 \%$ of sales; Bristol-Myers Co., $\$ 76$ million, nearly $40 \%$ of sales; and American Home Products Corp., $\$ 70$ million, over 12\% of sales. Larger percentage expenditures are undertaken for products that are sold frequently in small quantities to ill-informed buyers.

${ }^{20}$ See, e.g., Bailey's Bakery, Ltd. v. Continental Baking Co., Trade Reg. Rep. (Ig65 Trade Cas.) ๆ $7{ }_{358}$ (D. Hawaii, Sept. 24, 1964).

11 Producers that engage in intensive sales effort directed at consumers can sometimes, so far as the law allows, prescribe the equipment and much of the conduct of their distributors, confine each to a prescribed territory, fix resale prices, and require that no competing distributor's goods be carried. Examples have been numerous in the distribution of gasoline.

${ }^{12}$ See Estes Kefauver, In a Few Hands: Monopoly Power in AMerica 93-I03 (I965).

${ }^{18}$ Sec, for example, Hearings on Administered Prices Before the Subcomm. on Antitrust and Monopoly of the Senate Comm. on the Judiciary, 85th Cong., 2d Sess., pt. 6, at 268r-99, 2769-86 (1958).

14 The policies of particular countries are discussed in my forthcoming book, Trade Regulation Overseas: The National LAws, now in process of publication, and are analyzed comparatively in a second book, Control of Cartels and Monopolies: An Internationat Comparative Analysis, the manuscript of which $I$ have just finished.

${ }^{15}$ Sec, for example, Hearings on Administered Prices Before the Subcomm. on Antitrust and Monopoly of the Senate Comm. on the Judiciary, 85th Cong., Ist Sess., pt. I, at 50-5I (1957) (statement of John Kenneth Galbraith). 
between types of business conduct that are believed to contribute to desirable economic activity and types that have no such significance. Such a distinction sometimes influences judicial decrees. Because both types of conduct are affected when a monopoly is dissolved by law, judges deciding cases involving monopolization have sometimes curtailed remedial action lest efficiency be impaired. ${ }^{16}$ Some economists and lawyers are now asserting that this proper exercise of judicial discretion in determining the scope of a remedy should be converted into a discretionary standard of legality-that conduct thought to be desirable should therefore be held to be lawful. ${ }^{17}$ Thus far, this reinterpretation has been designed to relax existing law, not to extend it to cover what it does not now reach. But the logical corollary of such a policy would be that business conduct should also be unlawful when it is considered undesirable-that the test of legality should be not restraint of trade or effect on competition but efficiency in supplying economic needs. Under such a policy, a government could take corrective action against inflexible prices, high prices, functionless product differentiation, planned obsolescence, extravagant fancification of products, wasteful packaging, wasteful advertising, or any other type of business behavior it thought detrimental to an efficient economy. Pervasive regulation would replace the policy of maintaining competition.

The inadequacy of antitrust policy in coping with restrictive conduct by powerful firms might be reduced in a way more consistent with American antitrust policy by reducing the size and increasing the number of firms to a degree sufficient to restore the vitality of the price competition that is dead or has become anemic. Where feasible, this would be the simplest and most effective way of achieving the

\footnotetext{
${ }^{16}$ E.g., United States v. United Shoe Mach. Corp., I Io F. Supp. 295 (D. Mass. I953), aff'd per curiam, 347 U.S. 521 (I954).

${ }^{17}$ See, e.g., Bork \& Bowman, The Crisis in Antitrust; Bork, Contrasts in Antitrust Theory: I; and Bowman, Contrasts in Antitust Theory: $I I$, in The Goals of Antitrust: A Dialogue on Policy, 65 Colum. L. REv. $363,40 \mathrm{r}, 4 \mathrm{I} 7(\mathrm{Ig} 65)$. These articles presume that reduction of competition should be decmed to be the equivalent of reduction of efficiency. This is made particularly clear in the discussion of incipiency in the first article (id. at 368-69), in the contrast drawn between "efficiencies" and "restraints" in the second article (id. at 409-12), and in the following passage from the second article: "To the degrce that the law is consumer-oriented, the question of efficiency-the ability of the economic system to produce and distribute goods and services as inexpensively as possible-is fundamental. Efficiencies depend upon a wide variety of technical, managerial, financial, and organizational factors, howcver, and many of them are not susceptible of direct study and measurement. This means that the decision of most cases must be accomplished by the use of presumptions created with the guidance of economic analysis. ... Analysis seems to indicate that vertical and conglomerate mergers are capable of creating efficiencies and incapable of impairing competition. The strong presumption should, therefore, be in favor of their legality." Id. at 409-ro. The sentence about vertical and conglomerate mergers probably means "capable of creating efficiencies and therefore incapable of impairing competition." True, this is not said. But it is implied in that (a) neither article ever considers the case, crucial for the authors' argument, in which restraint of competition and increase of efficiency go together; $(b)$ in criticizing (id. at 369-70) passages in Judge Learned Hand's decision in United States v. Aluminum Co. of America, I 48 F.2d 416, 427, 429 (2d Cir. I945), that contrast (i) systems of production in which, "in spite of possible cost," units "can effectively compete with each other" with (ii) systems in which those engaged "must accept the direction of a few," the first article ignores the restrictive implications of the language used and focuses upon its cost implications; and $(c)$ the second article is a reply to one by Professors Harlan M. Blake and William K. Jones which argues that the goal of the antitrust laws is preservation of self-adjusting competitive markets.
} 
desired end. Politically, such a course of action would be difficult because it would arouse the simultaneous opposition of all large enterprises. Economically, it would involve the transitional costs that are inevitable in any substantial reorganization of industry. Moreover, by implying that a firm that grows big must suffer dissolution, it might dampen the desire to grow, which is one of the healthiest of competitive incentives. But, by restoration of self-regulating competitive markets, it would relieve both business and government of the heavy burdens and hard choices that are inevitable in government control of business conduct. It may be the only course consistent with long-run minimization of the role of government in controlling the operation of a private-enterprise economy.

Such a policy is not feasible, except at prohibitive social cost, where economies of scale have thrust bigness upon business enterprise. Doubtless there are such cases, but nobody knows how numerous and important they are. The big firms, which alone possess the information that is relevant to an appraisal of their relative efficiency, do not disclose it. Instead, they persistently offer self-serving assertions that they are big because they are efficient. The government has not obtained and analyzed the information requisite to an informed opinion on the point. The relevant fragmentary studies, public and private, contain indications that the obviously important technological economies of scale can be attained by firms of a size much smaller than the largest; ${ }^{18}$ but as to other types of economy they are inconclusive and in some respects contradictory. Moreover, such information and analysis as are available pertain almost wholly to the size of a big firm in a particular market or industry horizontally conceived. The vertical and conglomerate reach of large enterprises remains unmeasured ${ }^{19}$ and its relation to efficient performance unanalyzed. Nevertheless, the inevitability of big business on grounds of efficiency has been so widely taken for granted as to deprive of serious political attention the few proposals that have been made for comprehensive dissolution of big firms. ${ }^{20}$

\section{III}

Instead of basing policy toward big business upon a determination to keep the structure of business appropriate to the operation of self-regulating markets to the fullest extent that is feasible, the United States began in Igr4 to experiment with

\footnotetext{
${ }^{18}$ Sec Joe S. Bain, Industriat Organization 342-56 (I958).

10 The only available measures, those that compare the assets of groups of large manufacturing firms with aggregates for all manufacturing, fuse together the horizontal, vertical, and conglomerate dimensions of the firms. Attainment of a larger share of an important industry, extension across more successive stages of operation, and coverage of more numerous lines of activity have identical effects upon the apparent concentration.

20 The foremost of these, which appeared in 1959, is Card Kaysen \& Donald F. Turner, Antitrust policy. See also George W. Stocking \& Myron Watkins, Monopoly and Free Enterprise 563-64 (I95I); Joz S. Bain, Industrial Organization 608-io (1958); Corwin D. Edwards, Maintainino CoMpetrinoN 124-32 (1949); and Hearings on Economic Concentration Before the Subcomm. on Antitrust and Monopoly of the Senate Comm. on the Judiciary, 88th Cong., 2d Sess., pt. I, at 248-52, 353-78 (1964) (testimony of Walter Adams) [hereinafter cited as Hearings on Economic Concentration].
} 
laws designed to keep the conduct of large enterprises consistent with what is expected from competitors. ${ }^{21}$ The experiment was double-barreled. The Clayton $\mathrm{Act}^{22}$ was a precautionary effort to stop monopoly "in its incipiency" (a) by forbidding certain practices so far as they were likely to impair competition-price discrimination, exclusive dealing, and tying-and $(b)$ by forbidding certain methods of increasing business concentration-interlocking directorates and acquisitions of stock in competitors. The activities covered were those that, in Sherman Act cases, had seemed to have contributed most significantly to the development of monopolies. The Federal Trade Commission $\mathrm{Act}^{23}$ was an effort both to preserve competition and to regulate the quality thereof. The unfair methods of competition that it forbade were conceived partly as practices by which competitors were deprived of access to markets or of freedom of action therein and partly as practices otherwise undesirable. They included not only exclusionary, coercive, and collusive activities but also misrepresentation, bribery, and inequitable conduct that was damaging to competitors.

In subsequent legislation, the Congress extended the equitable reach of these laws. By the Wheeler-Lea Amendment ${ }^{24}$ business practices were brought under the Federal Trade Commission Act not only when they were unfair to competitors but also when they were unfair to consumers. By the Robinson-Patman Act, ${ }^{25}$ the price discrimination provisions of the Clayton Act were so amended as to forbid discriminatory practices not only when market competition was likely to be impaired thereby but also when inequitable treatment was likely to impair the opportunities of certain enterprises. ${ }^{26}$

That equitable control of conduct has a proper place in government policy is axiomatic to most men. It is questioned chiefly by scholars who take economic models so seriously as to believe that the only valid social goal is to maximize the productivity of the economy, that the institutions of property and contract accurately translate social product and social cost into pecuniary pluses and minuses, and that in spite of market imperfections the pursuit of gain leads everyone to do what is socially most desirable. To the rest of us it is obvious that competition, desirable though it is, does not necessarily prevent child labor, protect the health and safety of the working population, eliminate racial discrimination in employment and in sell-

\footnotetext{
${ }^{21}$ In the Sherman Act attempts to monopolize, as well as monopolization, had been forbidden. The prohibition was applicable, however, only where the purpose was clear, and, prior to the legislation of 1914, such a purpose was unlikely to be perceived unless monopolization was imminent. Thus the precautionary control of conduct reached little that was immune from the prohibition of monopoliza. tion.

3238 Stat. 730 (1914), as amended, I5 U.S.C. $\$ \$ 12-27$ (1964).

23 38 Stat. 717 (I914), as amended, I5 U.S.C. $\$ \$ 4 I-46,47-58$ (1964).

2452 Stat. III (1938), I5 U.S.C. $\$ \$ 4$ I et seq. (1958).

2549 Stat. 1526 (1936), 15 U.S.C. $\$ \$ 13-13 b, 21 a$ (1964).

${ }^{20}$ An equitable basis has also appeared in certain other commercial laws. For example, in the Automobile Dealer Franchise Act of 1956, 70 Stat. 1125 (1956), 15 U.S.C. \$\$ I 221-25 (1964), automobile dealers were given protection against practices by automobile manufacturers that the Congress thought inequitable, regardless of the effect of the practices upon competition.
} 
ing prices, or protect buyers from deception. We recognize the need for laws that determine the plane of competition and the limits of permissible conduct. Such legislation includes laws about working conditions and employment practices, food and drug laws, and numerous other statutes as well as the equitable provisions of the antitrust laws. In the aggregate, such laws divert competition from profitable types of conduct that are considered objectionable to types of conduct that are considered desirable or at least harmless. Like the laws of property and contract, they constitute a part of the regulatory matrix within which competition takes place. So far as they are self-consistent and intelligible, they necessarily imply, though they do not explicitly set forth, conceptions of the functions that competition can perform satisfactorily, the functions for which it is not effective, and the competitive conduct that is appropriate to the former functions. Thus they are relevant to the competitive policy. Indeed, ill-considered equitable laws can thwart desirable competitive conduct, and excessive scope for equitable laws could attenuate competition to the point where a regulated economy replaced a competitive one.

But though equitable laws that are ill-conceived or excessive can impair competition, well-conceived ones can do little to maintain the vigor of competition. The improvements in competitive results that are due to such laws spring from repression of kinds of competition that are undesirable. Desirable kinds of competition are not necessarily enhanced by such laws; they may be unaffected or may grow. stronger or weaker as is appropriate to the underlying incentives and opportunities to compete. If an adequate equitable code could be worked out, the activities of big business might be kept "fair," but they could not be kept competitive by such a code. Competitive innovations are novel, and hence cannot be described as fair; competitive achievements may exceed not only what was thought fair but also what was considered possible. Within limits set by society's concepts of fairness, the function of competition is to induce what standards of fairness do not or cannot require.

In spite of the relevance of equitable legislation to the competitive policy, such laws lie beyond the scope of this essay. To analyze differing conceptions of the proper functions of competition and regulation and to discuss the boundaries that regulation might set for competitive conduct in the light of this analysis would require an ambitious book. For present purposes, the antitrust laws will be conceived as efforts to keep competition vigorous within the boundaries set by equitable and other legislation, and discussion will be limited to the precautionary controls over the activities of individual firms that have this purpose. The equitable controls that are imposed in antitrust legislation will be considered only so far as they affect this purpose.

Moreover, the discussion of precautionary controls will be limited to the Clayton Act. The conclusions to which I am led by this discussion would not be significantly altered by the longer and more complex analysis that would be necessary 
if the diverse precautionary applications of the Federal Trade Commission Act were also discussed.

\section{IV}

The precautionary controls adopted in 1914 in the Clayton Act, and later extended in the Robinson-Patman Act and the Celler-Kefauver Act, ${ }^{27}$ are incomplete substitutes for a policy designed to keep the structure of markets sufficiently decentralized that markets can be self-adjusting. They do not impose structural correctives where market structure is now inconsistent with vigorous competition. Neither do they grapple directly with the phenomena of sticky prices, meaningless product differentiation, wasteful planned obsolescence, de facto control of distributors by suppliers, and impairment of consumer choice by excessive promotional effort, by which defective competition often manifests itself. Instead, on the implied premise that existing business, so far as it does not violate the Sherman Act, is adequately competitive, they merely attempt to prevent future reduction of competition by forbidding activities that are likely to have competition-reducing effects. Such a policy is inadequate to the extent of the inadequacy of its premise that the Sherman Act can cope with all significant existing impairments of competition.

Within their own modest limits, however, these precautionary controls have an important function to perform-to make sure that the prospects of competition shall grow no worse. They can perform this function satisfactorily only if (a) activities that tend to reduce competition can be identified and prevented without substantial damage to activities that have no such tendency and $(b)$ prevention of the anticompetitive activities is sufficient to forestall an anticompetitive trend in industrial organization.

Attempts, like those of the Clayton Act, to control business conduct in order to prevent the lessening of competition assume (a) that reduction of competition is a result of specified kinds of conduct, $(b)$ that this result is not invariable, and (c) that it can nevertheless be foreseen with reasonable accuracy by examining the conditions under which the conduct takes place. The first assumption is not tenable so far as the results of conduct are indeterminate or depend upon the interaction of an indeterminate number of different types of behavior or consist of an indissoluble blend of reductions of competition in some respects and enhancements of it in others. To accept this assumption one must presuppose that the types of conduct that are specified have characteristic one-sided results, either invariably or under particular circumstances. If this is true, conduct with invariable anticompetitive consequences can be categorically forbidden; a conditional prohibition of it would presuppose that this effect is not inevitable. Such a conditional prohibition would be futile if the circumstances that determine the anticompetitive effect would not be detected soon enough to avert it. The Congress that enacted the Clayton Act

\footnotetext{
${ }^{27} 64$ Stat. Ir25 (1950), 15 U.S.C. \$ 18 (1964).
} 
failed to identify any kind of business conduct that was so invariably anticompetitive as to be forbidden under all circumstances. It eventually devised only four prohibitions. Of these, one was made applicable only to competing corporations larger than a specified size. The other three were made applicable in circumstances, not further defined, in which their probable effect would be a substantial lessening of competition or a tendency toward monopoly. After half a century of experience and two substantial amendments, the law's precautionary provisions have the same orientation. ${ }^{28}$

In the Clayton Act, as amended, the significant precautionary provisions are the curbs upon price discrimination, ${ }^{20}$ exclusive dealing and tying arrangements, ${ }^{30}$ and corporate acquisitions of stock or business assets. ${ }^{31}$ (The act's additional substantive provision that seeks to preclude personal links between competing corporations through common directors was so badly devised that it may be ignored as meaningless. ${ }^{32}$ )

\section{A. Tying Arrangements}

In the case of tying arrangements, the conditions requisite for precautionary control of conduct have been present. A seller cannot undertake to condition the sale of one product, or the offer of it at a low price, upon a requirement that the purchaser also buy another, unless he has a substantial degree of control over the supply of the first; and he will seldom do so for any purpose other than to foreclose

\footnotetext{
${ }^{28}$ In the $19 I_{4} \mathrm{law}$, acquisitions of stock were made illegal if they probably would reduce competition either in the market or among the corporations involved in the acquisition. The I950 amendment eliminated the latter test. In the Robinson-Patman Act, transmission of brokerage from a party on one side of a transaction to a party on the other was made illegal under all circumstances; promotional payments and promotional services by a seller were made illegal if disproportional among his competing customers; and price discrimination was made illegal not only when likely to impair market competition but also when likely to reduce the competitive opportunities of those discriminated against. These features of the act reflect its equitable purposes, not its precautionary ones.

${ }^{30}$ Sec. 2, as amended, 49 Stat. 1526 (I936), 15 U.S.C. \$ 13 (1964).

${ }^{80}$ Sec. 3,38 Stat. 731 (I9 4 ), I5 U.S.C. $\$ 14$ (Ig64).

${ }^{31}$ Sec. 7 , as amended, 64 Stat. II25 (I950), I5 U.S.C. $\$ 18$ (I964).

${ }^{32}$ Sec. 8 of the act, $3^{8}$ Stat. 732 (I9I4), as amended, 49 Stat. 717 (I935), I5 U.S.C. $\$$ I9 (I964), applying to interlocking directorates between competitors, was so badly drafted that evasion of its purpose is easy. Since the prohibition is not addressed to the corporation but only to the particular person who has a dual directorship, an order that terminates the illegal relationship applies to the offending person alone and not to another person who may succeed him in the same dual capacity. There is a serious question whether such an order can be stretched to forbid the competing corporations to employ such a successor. Moreover, though the law applies to interlocking directors, it does not explicitly apply and has not been extended by interpretation to apply to interlocking corporate officers nor to an interlock between a directorship in one company and an office in another nor to employment of the principal stockholder of one company as officer or director of another. Neither does it forbid the boards of directors of competing companies from being linked by brother and brother, husband and wife, father and son, partners in legal or accounting or advertising firms, or different directors of the same bank or the same corporate supplier or customer. Because of these weaknesses, violation of the law is not necessary to establish a personal bond between corporations; and, where violation does occur, enforcement of the law cannot accomplish significant results.
} 
the opportunity of those who compete with him in selling the second. Thus an anticompetitive tendency inheres in this practice, so much so that there would be only occasional irrelevance in forbidding it wholly. But since, except in periods of acute shortage of goods, the practice can be adopted only under conditions in which the supply of a commodity is under concentrated control, prohibition of it succeeds only in preventing the spread of existing dominance from one commodity to another. It does not prevent the initial attainment of dominance.

What the law accomplishes, however, is achieved without great difficulty. Since the meaning of the law is clear and violations are not hard to detect, there is relatively little violation. In such legal proceedings as arise, proof is not difficult, and there is little need to disentangle harmful tying from harmless or useful tying. The law accomplishes its limited precautionary purpose.

\section{B. Price Discrimination}

Experience with the law of price discrimination has given ground for doubt that anticompetitive discrimination can be adequately identified, segregated, and prevented wth adequate effect upon structural diffusion. The Robinson-Patman Act has the purpose of preventing the use of price discrimination as a means by which powerful sellers can selectively weaken their competitors and powerful buyers can get buying advantages that are decisive in resale markets. Pursuit of this purpose necessarily requires a choice between two interpretations of it: first, one in which the objective is merely to preserve enough sellers and buyers to assure the vigor of competition in markets at each successive level and, second, an interpretation in which the objective is to prevent discrimination from depriving any substantial number of sellers or buyers of opportunity to compete. Since the Robinson-Patman Act has equitable as well as competitive goals, the latter interpretation has prevailed.

Though some of the difficulties that have developed are probably due to this interpretation, the law has been unsatisfactory even under the first interpretation. Discrimination that damages competition has been hard to distinguish from discrimination that merely recognizes and reacts to the varying intensity of competition in imperfect markets. For this reason, the law has handicapped sellers in responding flexibly to varying circumstances and has given rise to enduring controversy about the proper limits of the right to discriminate in order to meet competition. Discrimination that is an incident in the process by which price changes spread has been hard to distinguish from discrimination that creates enduring competitive advantages. For this reason the law has created hazards for those who try to drive hard bargains. Discrimination sometimes produces mixed effects, enhancing competition among oligopolistic sellers while diminishing it among their customers. Under such circumstances, the law condemns the diminution and ignores the enhancement. Because of the law's inherent ambiguities, businessmen can now vary their selling prices or haggle over buying prices only with caution and under legal 
guidance. Whether, on balance, the law has maintained more competition than it has impaired is uncertain.

Moreover, discrimination is a complex phenomenon which the law may change in form without eliminating. The likelihood of this result is greatest where enterprises are most powerful. A powerful seller, forbidden to divert trade from particular competitors by selectively reducing the price of one kind of goods in particular parts of a market, can do so instead by making uniform price reductions upon the part of its product-line that is most important to particular competitors. A powerful buyer, deprived of discriminatory price concessions, can still obtain special advantages in acquiring goods. It can (a) take a seller's entire output at a low price; (b) obtain low prices from sellers who are meeting some other seller's lawful competition; $(c)$ buy goods cheaply abroad; $(d)$ obtain low prices upon goods so differentiated from what bears higher prices that the prohibition of the law is inapplicable; $(e$ ) obtain goods of premium quality without paying a premium price; $(f)$ buy large amounts under long-term contract when prices are unusually low, or (g) produce goods for itself. Powerful sellers can sometimes refuse to sell instead of discriminating. Moreover, they and powerful buyers alike can resort to discriminatory competition in sales expenditures: Powerful manufacturers can selectively saturate parts of their markets with advertising and other promotional outlays, to the detriment of their weaker rivals, so long as they do not do so in ways that discriminate among their competing distributors. Instead of passing on discriminatory price reductions to their resale markets, powerful chain stores can woo their customers with longer and more varied lines of merchandise, free parking facilities, and intensified advertising and can do so selectively in particular localities.

With possibilities such as these still open, the Robinson-Patman Act has been a weak instrument with which to prevent whatever concentration of economic power may result from discrimination. Its principal achievements have been equitablediminution of various inequalities in the terms of trade available to weak distributors. The degree of this achievement has tended to be greatest in eliminating discriminations that were not very important to corporate empire-builders.

\section{Exclusive Dealing}

Experience with the law against exclusive dealing has also been unsatisfactory. The purpose of the law is clear-to prevent arrangements that, by linking particular sellers and buyers in exclusive (or preferential) relationships, prevent others from competing for business with them. But, as in the case of the Robinson-Patman Act, this purpose may have alternative interpretations: either to preserve the competitive opportunities of the community of traders or merely to keep the number of traders large enough to assure vigorous competition in the market. Choice between these interpretations is not affected, as in the Robinson-Patman Act, by any statutory announcement of a supplementary equitable goal. 
Whatever the interpretation, the appropriate scope of the law is not clear. An exclusive arrangement may cover a large part of a market or a small one for a long period of time or a short one. At its smallest and briefest, it may involve a restriction of opportunity for others that is scarcely greater than that which is inevitable in the sale or purchase of a substantial quantity of goods. The smaller the exclusive arrangement relative to the total volume of the goods that is available or that is customarily bought by the distributors of a particular market, the greater is the probability that third parties will have access to adequate alternatives. The largest and most enduring arrangements are the ones most likely to have preclusive effects. But it is difficult to determine the degree of exclusiveness below which there is no probability of an impairment of competitive opportunity.

Moreover, many exclusive arrangements are made not to deprive third parties of access to the market but to provide an assurance of supply that will justify substantial expenditures for facilities or for promotion that would not otherwise be profitable. In such cases, there is a possibility that competition between firms that are parties to different exclusive arrangements will enlarge the total market without significant damage to anyone's opportunity. To distinguish such situations from those involving preclusion is not easy.

Most of the arrangements actually condemned have involved action by powerful suppliers to establish enduring control over a considerable part of the country's relevant distributive facilities, thus narrowing substantially the field that remained open to independent suppliers. Condemnation of them has been appropriate to the effort to diminish tendencies toward concentration. But the cases have been few and their aggregate effect meager. Had they been numerous enough to have significant aggregate meaning, the interpretative difficulties that are mentioned above would probably have become formidable. Awareness of this probability by the law enforcement authorities appears to have been significant in reducing the number of proceedings; even in the period between the Standard Stations case ${ }^{83}$ and the Tampa Elec. case, ${ }^{34}$ when the authority of the Supreme Court appeared to support the view that any exclusive dealing arrangement involving a substantial amount of commerce was illegal, the many exclusive arrangements in the sale of automobiles, household appliances, and gasoline persisted with few legal challenges.

Any broad effort to apply the law about exclusive dealing to powerful firms would be handicapped not only by the interpretative difficulties mentioned above but also by the fact that this law, like the Robinson-Patman Act, can be circumvented. Vertical exclusiveness may be established, as a dissent in the Standard Stations case indicated, ${ }^{35}$ by ownership as well as by contract. The law is not an obstacle to vertical self-supply. Firms in the vertical line may be acquired, or, if

\footnotetext{
${ }^{83}$ Standard Oil Co. v. United States, 337 U.S. 293 (I949).

${ }^{83}$ Tampa Elec. Co. v. Nashville Coal Co., 365 U.S. 320 (Ig6r).

${ }^{85} 337$ U.S. at $3 \pi 5-2 x$.
} 
acquisition is blocked, an enterprise may expand vertically. By one method or the other, a chain store may manufacture its private-branded goods, an oil company may operate its own filling stations, and a large tire distributor may own molds in which tires are produced for it from its own rubber by a large tire maker who receives a processing fee. To forbid exclusive dealing by powerful firms is to increase the incentives to create similar vertical structures.

VI

Except in the case of tying arrangements, the precautionary controls over market behavior in the Clayton Act have achieved little and promise little as means to prevent further growth of anticompetitive concentration. If they are used ambitiously, they necessitate decisions about the future effect of conduct upon competition that are not possible; hence it is uncertain whether they will preserve or impair competition. If they are used modestly, they are unlikely to have sufficient effect to counteract the development of an oligopoly. They may prevent a firm already dominant in one field from extending its dominance into another by resorting to the types of conduct to which the law applies, but are likely to result in use of some alternative way of exerting dominant power that accomplishes the same business purpose.

The law against mergers has substantially greater potential. It strikes directly against concentration and is thus clearly pertinent to any reductions of competition that might result from concentration. An effective version of it has been available for only fifteen years, as compared with nearly thirty years for the Robinson-Patman Act and more than fifty years for the provisions against exclusive dealing and tying. The test cases that will determine its interpretation are still in progress. Nevertheless, it has already had preventive effects upon enhancement of concentration in certain fields such as steel ${ }^{36}$ and milk ${ }^{37}$ and appears to be capable of similar effects on a much wider scale.

The importance of this law is evident in the fact that acquisitions of some business enterprises by others have contributed significantly to business concentration in the past and appear to be doing so now. The merger movement around the beginning of this century was one of the developments by which oligopoly on a national scale became an important aspect of American economic life. ${ }^{38}$ During this period, some of today's largest companies attained by merger a place among the country's dominant firms that they have not subsequently lost. As is illustrated by the case of United States Steel Corp., leadership thus attained can give economic

\footnotetext{
${ }^{86}$ United States v. Bethlehem Steel Corp., I68 F. Supp. 576 (S.D.N.Y. I958).

${ }^{37}$ See address of Willard Mueller, Director, Bureau of Economics, Federal Trade Commission, "The Current Merger Movement and Public Policy," before the Faculty of Business Administration, University of Florida, Gainesville, Fla., May I6, I963, pp. 9-12 (mimeo.).

${ }^{38}$ See Ralph L. Nelson, Merger Movements in Amierican Industry, I896-I956, at Ior-03 (1959); Hearings on Economic Concentration 13-15 (testimony of Gardiner C. Means).
} 
strength great enough to endure, though in diminished degree, through considerable periods of gross inefficiency and laggard innovation. ${ }^{39}$ The merger movement of the I920's, while less significant as a source of concentration, contributed substantially to the vertical stretch and horizontal diversification of large companies. ${ }^{40}$ Since I950, significant numbers of important firms have disappeared by mergers, and the country's largest and most powerful firms are conspicuous among those that made the acquisitions. ${ }^{41}$ Many of the country's leading firms owe a substantial part of their growth to mergers. ${ }^{42}$

The merger law can be used vigorously as a weapon against concentration because its use is unlikely to entail social costs as high as those that might be involved in a program of dissolution of large enterprises. Widespread dissolution might deprive the larger firms of incentives to grow bigger and thus weaken their incentives to reduce prices and costs and to innovate. Widespread prevention of mergers would leave such incentives intact except that the path to larger size would be internal expansion instead of external acquisition. Moreover, wherever the existing size of firms is requisite to economies of scale, a dissolution program could be undertaken only at significant social cost, particularly since substantial scale economies might be found to exist most frequently in oligopolistic firms that have been developed as coherent business units. Similar problems of economy of scale are likely to be encountered only seldom in preventing mergers, for the merging firms were not designed to operate as single units and are not likely to operate as such with the efficiency that a firm could attain by expansion. For a particular enterprise, expansion by merger may be a quick way to expand and to attain whatever advantages may be derived from bigness. For the economy, it is an unpromising way to build functionally efficient enterprises.

In forbidding any merger that probably will lessen competition substantially, the amended merger law is applicable to all kinds of mergers, horizontal, vertical, and conglomerate. Its application to horizontal mergers is directly relevant to diminutions of competition by oligopoly such as have been discussed above. Its

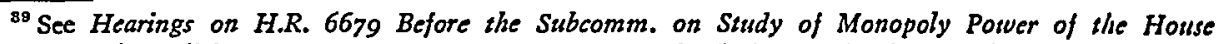
Comm. on the Judiciary, 81st Cong., 2d Sess., ser. 14, at 965 ff. (1950) (testimony of George W. Stocking).

${ }^{10}$ Hearings on Economic Concentration $13-15$ (testimony of Gardiner C. Means).

"According to the Federal Trade Commission's chief economist, between $\$ 19$ billion and \$20 billion of assets were acquired by merger from 1948 to 1963 , which amounted to $22 \%$ of the total value of all corporate assets in manufacturing and mining for 1948 , or $8 \%$ of that total for 1963 . Firms that disappeared by merger included 15 of the country's 200 largest manufacturing corporations, and 216 of the 1,000 largest. The merged manufacturing firms in the size class from \$1o million to $\$ 250$ million of assets had aggregate assets equal to $20 \%$ of all assets possessed by firms in that size class in 1963 . As a group, the 200 largest manufacturers acquired 1869 firms with nearly $\$ 14$ billion in assets, including 82 of the largest $\mathrm{I}, 000$ manufacturers. Their acquisitions equalled nearly $22 \%$ of the total assets they possessed in 1950 , more than $8 \%$ of the total assets they possessed in 1962 , and nearly $16 \%$ of their total asset growth. For 23 of them, acquisitions exceeded $50 \%$ of total asset growth. See Hearings on Economic Concentration 123-29.

${ }^{12}$ See Hearings on Economic Concentration $160-81$ (testimony of Harrison Houghton, Assistant to the Director, Bureau of Economics, Federal Trade Commission).
} 
application to vertical and conglomerate mergers is relevant to other aspects of economic power about which we know less and differ more widely in opinion.

\section{A. Horizontal Mergers}

The need for vigorous action against anticompetitive horizontal mergers is clear. Available information indicates that levels of concentration of a height that often impairs vigorous competition exist in numerous industries and that, in a significant number of these industries, high concentration has persisted or increased for more than a decade. ${ }^{43}$ This fact establishes the desirability of a merger policy designed to deter anticompetitive horizontal concentration. The frequency and trend of high concentration are relevant to an appraisal of the magnitude of the effect that may be expected from prevention of horizontal mergers but not to the need for precautionary action in the field where persistent high concentration exists.

In cases against horizontal mergers, the principal need is to develop, by amendment of the law or by interpretation of it, legal and economic rules of thumb capable of expediting the cases and enabling the enforcement agencies to cover their field more adequately. The horizontal merger cases that have been actually brought have involved chiefly relatively large mergers by relatively large national firms. Where mergers are of this magnitude, it is clear that their prevention is usually significant to the oligopoly problem. Though the present elaborate analyses of relevant markets and competitive effects enhance the precision with which merger policy is applied in such cases, this gain is obtained at great cost in delayed decisions, fewer proceedings, and lack of voluntary compliance. Little would be lost and much gained if we established rebuttable presumptions (a) that, for firms that operate nationally, census five-digit product classes constitute relevant markets and $(b)$ that substantial lessening of competition would be probable if such a firm were a party to a merger after which the merged firm controlled a stated significant portion of the total supply. The force of the second presumption could be enhanced if parties to a merger who undertook to rebut it were required to show that the merger probably would be not merely harmless to competition but actually beneficial to it. Under such a rule, the parties to a merger would carry the burden of proving that the definition of the market was clearly wrong or that a market share greater than the stipulated percentage was necessary to preserve the existence of a failing firm, to enable the merging companies to compete effectively against a much larger firm, or otherwise to preserve or enhance competition. If the practical

\footnotetext{
${ }^{43}$ High levels of concentration in 1958 are summarized in Hearings on Economic Concentration 89, for major industries, and $i d$. at 325 for all industries. For changes in concentration in inclustries, see id. at $67-68,75,127,325$, and 447 . The figures about change show change both ways, with decreases more numerous than increases. For antitrust policy, however, the significant fact is that there have been increases in numerous industries, including some major ones and some, both major and minor, that have high concentration ratios. The extent of the condition is relevant not to the need for corrective action but to the proportion of the economy in which the need arises.
} 
effect were that the major national firms undertook almost no mergers with competitors, this result would be desirable.

If some such rule of thumb were to be applied, cases would arise to which the rule was only partly applicable or not applicable at all. Relevant territorial markets would need to be determined for firms of less than national scope, but, within such markets, five-digit product groups could be regarded as presumptively appropriate measures of the market's product extension. In addition, market shares equivalent to those used in the nationwide formula could be treated as presumptive indications of anticompetitive effect. In particular instances, anticompetitive effects might be probable from mergers involving a commodity group narrower than a five-digit census classification or involving firms too small to attain the designated market share by combination. In these cases, those who enforce the law would need to establish the scope of the relevant market and the nature of the anticompetitive effects without the aid of presumptions. But failure to cover such situations comprehensively and adequately would be less important if limits to further growth by merger had been set by presumptions like those that are here suggested.

A more difficult horizontal problem is raised by mergers of potential competitors. In such cases, the effect of the merger upon competition depends upon two matters: (a) the likelihood that actual competition will develop and $(b)$ the competitive stimulus that each company experiences from the mere possibility that the other will become a competitor. Though the principle should be clear that mergers of significant potential competitors should be forbidden, rules of thumb can do little or nothing to simplify the application of it.

\section{B. Vertical Mergers}

Vertical mergers raise problems still more difficult. Since economic analysis typically relates to simplified theoretical models in which producers deal directly with consumers, economic theory has offered little guidance about the problems that arise when production and distribution involve several successive levels of activity. In the absence of a comprehensive vertical theory, a few starting points for policy may be noted: (a) there is no obvious reason why the vertical boundaries of enterprises should be set at any particular point; $(b)$ there is considerable persuasiveness in the idea that firms of different vertical dimensions should compete with one another so that the viability of each type of structure would be tested by competition; (c) there is reason to doubt that our policies toward close coordination of activities at successive vertical stages of production and distribution should differentiate, as they now do, between vertical control inherent in ownership and vertical control established by requirements contracts or contracts for exclusive dealing, and (d) there is reason to think that vertically, as well as horizontally, efficient coordination of activities is more probable through coherent growth than 
through merger. So far as these four points have implications for policy toward vertical mergers, the first two of them suggest a permissive attitude toward such mergers, the last suggests a repressive one, and the third suggests merely that this part of the merger law and the law of exclusive dealing should be harmonized.

In three situations the undesirability of vertical mergers seems clear. The first is that in which a firm engaged in such a merger has a dominant position in a horizontal field. Since, if such a firm acquires a place in a vertically related field, it can use price squeezes, discrimination in orders or in supply of goods, and similar tactics to extend this dominance vertically, it should not be allowed to consummate vertical mergers. The second situation is that in which a horizontal field has been oligopolized to the detriment of competition in the ways previously discussed and competition in the field that one of the oligopolists proposes to enter by vertical merger has not been similarly impaired by oligopoly. In this type of case, one vertical merger is likely to lead to another with the result that anticompetitive oligopoly spreads vertically. The third situation is that in which, by reason of substantial difference in the horizontal extent of vertically related markets, a firm not dominant in the wider market could by merger readily become dominant in the narrower one because its resources were disproportionately large relative to other firms in that market. Most of the cases in which vertical mergers have been challenged seem to me to have involved such situations.

Except when associated with dominance or with oligopoly, however, foreclosure of some part of a vertical market has dubious merit as a test of probable harm to competition. Every vertical merger is likely to foreclose the parts of the related markets that are common to the merged firms. Neither this fact nor the possibility that certain similar vertical mergers may follow should be regarded as a demonstration of probable competitive injury if, after the mergers, each of the vertically related markets remains sufficiently nonconcentrated to make vigorous competition probable.

\section{Conglomerate Mergers}

The most significant and most difficult aspect of the merger law is probably the prevention of anticompetitive conglomerate mergers. Most mergers in which large enterprises now participate appear to be designed partly or wholly to extend a line of products, to extend the sale of existing products into new territory, or to unite wholly unrelated activities.

Such mergers contribute to a concentration of control over economic life that may have anticompetitive consequences. In manufacturing, the only segment of the economy for which we have good estimates of concentration, a few firms now occupy a large part of the total field. The largest fifty firms furnished in 1962 about twenty-four per cent of all value added by manufacturing, the largest 100 firms furnished about thirty-two per cent, and the largest 200 firms accounted for 
about forty per cent. Of all manufacturing assets, the largest fifty firms possessed at least thirty-five per cent, the largest 100 at least forty-five per cent, and the largest 200 about fifty-five per cent. Of manufacturing profits after taxes, the largest fifty received nearly forty-eight per cent, the largest roo nearly fifty-eight per cent, and the largest 200 more than sixty-seven per cent. ${ }^{44}$ The available information indicates that these percentages have grown substantially since the end of the second World War. ${ }^{45}$

Much of the existing bigness of these big firms is due to the important place that each has in one or more large industries, and a part of the recent enlargement of their place in manufacturing has been due to the growth of their industries in proportion to the rest of the economy. But, in general, the larger the firm, the greater is the number of its plants and products. A substantial part of the bigness of the big is due to diversification, and a substantial part of the increase in bigness has been due to increase in diversification. ${ }^{46}$ The potential for further growth in the relative size of the big companies consists chiefly in their capacity to diversify still further.

Curbs upon growth by diversification are necessary lest manufacturing as a whole be dominated by a few very large companies. The degree of over-all concentration that seriously jeopardizes the economy is uncertain. But it is clear that beyond some point further increase in the share of the economy controlled by a few large enterprises must impede competition. If, for example, the whole manufacturing economy were controlled by fifteen firms, competition would suffer even if every firm were engaged in every industry and if fifteen proved to be a number too large to constitute restrictive oligopoly in the particular industries. Sources of goods, job opportunities, innovations, and funds for expansion would be too few for the survival of a competitive system. Entry into manufacturing by newcomers would be impeded by the fact that a few enterprises with great resources controlled all the existing facilities, employed all the experienced managers and technicians and all the labor that had relevant skills, possessed all the relevant technology, and exerted great influence upon the sources of materials, the channels of distribution, and the capital markets. When the diversified fifteen firms competed with one another, each would have available the possibility of subsidizing one activity from the proceeds of another, striking where maximum damage could be inflicted with the minimum commitment of resources, and forming alliances with others by reciprocal

\footnotetext{
"Hearings on Economic Concentration $113-15$ (testimony of Willard F. Mueller, Director, Burcau of Economics, Federal Trade Commission); id. at 8o (testimony of John Blair).

${ }^{45}$ Responsible estimates indicate that the share of the largest 50, 100, and 200 corporations in total value added by manufacture increased from 1947 to 1962 by 7,9 , and to percentage points, respectively; that their share in manufacturing assets increased from 1950 to 1962 by nearly 5 , more than 6 , and nearly 8 percentage points, respectively. Comparisons for profits are not available. Sec Hearings on Economic Concentration 80-81, 121 .

${ }^{16}$ Hearings on Economic Concentration $84-85$ (testimony of John Blair); id. at $156-60$ (testimony of Harrison Houghton).
} 
trading. Each would also be exposed to similar strategies. Thus intense competition would be peculiarly dangerous. Like great political states, the diversified fifteen would be likely to temper their competitive pursuit of advantage in one of their many fields of activity because each would know that vigorous warfare in one field might lead to retaliation elsewhere and that the conflict might come to cover so wide an area and require such a large commitment of resources as to be clearly unprofitable.

The kind of danger to competition that has just been sketched is the cumulative effect of excessive concentration by diversification. It is not the result of a particular conglomerate merger but the aggregate effect of all of them. Since the field of manufacturing is large, only the largest mergers could make, individually, more than a slight change in the aggregate share of the largest companies. This fact, plus the fact that the chance of increased efficiency by conglomerate merger is not great, might suggest that the way to avert excessive conglomerate concentration is to forbid all conglomerate mergers without regard to their individual effect.

But there are reasons to avoid such a policy, at least now. In some instances, entry by a large established firm into an additional field of business may be the most practicable or even the only practicable way to overcome obstacles to entry and enhance competition in an oligopolized industry. In some instances, especially in the case of relatively small companies that diversify by market extension or product extension, diversification may enhance efficiency by making possible a volume of activity that permits economies of scale in the part of operations that is common to the diverse markets, such as power supply, inspection and quality control, or functionally specialized management. To allow for such possibilities, conglomerate mergers should be prevented in the cases in which they individually tend to reduce competition, and general repression of them should not be undertaken unless it appears that the policy of selective repression is insufficient to stop the concentrative trend.

The peculiarity of a conglomerate merger is that it diminishes the susceptibility of a firm to the discipline of any one market, enhances the kind of power that can be obtained from dispersion of resources, and enables a firm to attain greater aggregate size. No coherent and generally accepted analysis of the significance of such developments is yet available. In my opinion, however, the anticompetitive results that are most likely to reflect the special characteristics of this kind of merger are those that result from subsidization, reciprocity, full-line selling, and a "live-and-letlive" attitude toward competition. ${ }^{47}$

\footnotetext{
"In 1958, about $24 \%$ of the total employment by the 200 largest manufacturing companies fell outside the 2-digit industry groups in which the firms were principally engaged. In I 962, the $x, 000$ largest manufacturing corporations included 728 that made shipments in more than 55 -digit product groups, $25 \mathrm{I}$ that did so in more than 15 such groups, and 15 that did so in more than 50 such groups. Between 1950 and 1962 , the number of firms with more than 5 product classes increased by 160 , of firms with more than 15 product classes, by 108 , and of firms with more than 50 product classes, by 7 .
} 
The opportunity to use subsidization as a competitive weapon is inherent in the competition of a diversified firm with more specialized competitors. A diversified firm can mobilize its liquid resources where it wishes and thus can afford to spend, lose, or invest, in any one field, more than its operations in that field have made available to it there. It is thus strengthened against the momentary limitations that confront its specialized competitors. By diverting resources from other parts of its operations, it can take fuller advantage of opportunities and is more capable of withstanding temporary losses. In making decisions that involve risk, it can therefore afford to be less cautious. It can use its advantage in mobility of resources to discipline or harass specialized firms, and knowledge that it can do so is likely to make them docile and responsive to its leadership. By allocating its joint costs and overhead costs to the part of its business in which it encounters the least competition, it can enduringly provide the equivalent of a subsidy to reduce its costs of operation where its competitors are strongest. If its market structure and its cost structure are both complicated, the costs of particular parts of its activity may be so difficult to determine that subsidization becomes not a deliberate policy but a "natural" response to competitive forces. But, whether consciously or unconsciously, a diversified firm with heavy joint costs that allocates them in accord with what the traffic will bear may reduce the competitive opportunity of its specialized competitors in the lines of business in which its operations are thus subsidized.

The opportunity to use reciprocity-that is, to insist that those who sell to a firm shall also buy from it-is derived from the magnitude of a firm's purchases. When the firm's size is increased by any means other than vertical integration, its purchases increase and its ability to use such a policy increases also. When a large firm grows bigger by conglomerate merger, it increases the volume of its buying and probably also the diversity thereof. Its aggregate purchases from particular firms are likely to increase, and so is the number of firms from which it makes substantial purchases. If it relies on reciprocity in selling, its leverage for so doing is enhanced, and the opportunity for its competitors to make sales is correspondingly reduced.

The opportunity to undertake full-line selling is increased by the type of conglomerate merger that extends the line of products. By joint promotion of the various items in a line of products, a diversified firm can enhance its selling expenses and increase the differential impact of them without increasing the sales cost per item sold. It may be able to become more nearly the sole supplier of its distributive outlets and may thus create difficulties for its competitors in obtaining comparable cooperation from these outlets. It may attain a sufficient volume of related goods to enable it to integrate vertically instead of using independent distributors and may

See Hearings on Economic Concentration 157, 159, 388. See also id. at 41-45 (testimony of Corwin D. Edwards). 
either do so or use the possibility of doing so as leverage in its dealings with the independents.

A "live-and-let-live" approach to competition may arise between two or more great diversified firms long before conglomerate concentration has made this attitude characteristic of most big business. As rivals in many markets, such competitors may think it wise to consider the effect of competition at any one point upon the nature of their competitive relationship at many other points. Each may be aware that the other is a formidable competitor because of its resources, its power to subsidize, and its ability to retaliate in the particular fields most important to its rival and least important to itself. Each may envisage price competition as something likely to spread from market to market, with aggregate losses that probably would outweigh any localized gains. Where such ideas acquire force, they may lead to informal reciprocal recognition of each firm's primary interest in particular fields of activity in a way similar to that by which national states sometimes avoid conflict by reciprocally recognizing spheres of influence.

\section{Conclusions on Antimerger Policy}

The potential of the antimerger policy is not yet clear. It depends partly, but not wholly, upon how the law is interpreted and how vigorously it is administered. In over-all impact, however, the effect of the policy depends upon the question whether it can affect the relation between the rate of growth of big business and the rate of growth of the economy. If the economy grows faster than big business, this fact will necessarily tend to reduce the aggregate anticompetitive effects that may now be created by oligopolies and by vertical and conglomerate concentration. The inadequacy of the Sherman Act to cope with such phenomena will decrease in importance. The present laws will become increasingly adequate for their purpose. Their localized failures will be unlikely to become more numerous and important. If the economy and big business grow at about the same rate, as some observers say has been true for about two-thirds of a century, our economic expansion will provide no general mitigation of antitrust difficulties. The problems that concentration now creates will remain with us unless we devise new solutions for them.

But if, in spite of the antimerger policy, the growth of big business outruns the growth of the economy, drastic changes in antitrust policy probably will become inevitable. 